\title{
Inefficient Inequality: The Economic Costs of Gender Inequality in Europe
}

Much attention is given to the existence and measurement of gender inequality, but relatively little attention is given to the economic costs that result from the presence of inequality. This topic was the focus of our November 2016 conference at the Centre for European Policy Studies in Brussels. We invited a diverse group of speakers to discuss their research on the costs of inequality in the labour market and beyond. Published here are the conference papers of those proceedings. What is apparent is that while the quest for gender equality is a necessity in itself as a matter of justice and fairness, the existence - and persistence - of inequality has a significant effect on the economic performance of Europe.

Unlocking the Potential of Greater Female Employment in Europe

Lone Christiansen, International Monetary Fund, Washington DC, USA.

Huidan Lin, International Monetary Fund, Washington DC, USA.

Joana Pereira, International Monetary Fund, Washington DC, USA.

Petia Topalova, International Monetary Fund, Washington DC, USA.

Rima Turk, International Monetary Fund, Washington DC, USA.

Gender Inequality and Growth in Europe

Stephan Klasen, Georg-August-University Göttingen, Germany.

Anna Minasyan, Georg-August-University Göttingen, Germany.

The Gender Employment Gap: Costs and Policy Responses

Martina Bisello, Eurofound, Dublin, Ireland.

Massimiliano Mascherini, Eurofound, Dublin, Ireland.

Gender and Inequality: Austerity and Alternatives

Diane Perrons, London School of Economics and Political Science, UK.

Gender Equality in Decision-Making Positions: The Efficiency Gains

Paola Profeta, Bocconi University, Milan, Italy. 